\title{
Warming and drying of tundra and glacier summer climate in NW Spitsbergen from 1975 to 2014
}

\author{
Rajmund PRZYBYLAK and Andrzej ARAŹNY \\ Katedra Meteorologii i Klimatologii, Wydział Nauk o Ziemi, Uniwersytet Mikołaja Kopernika, \\ ul. Lwowska 1, 87-100 Toruń, Poland \\ $<r p 11 @ u m k . p l><a n d y @ u m k . p l>$
}

\begin{abstract}
Temperature and precipitation conditions in the Kaffiøyra region in the summer season (21 July-31 August) for the period from 1975-2014 are described based on data collected during 22 expeditions, in which meteorological measurements were carried out, and complete data series combining both original and reconstructed data. The latter ones were obtained using data from the Ny Ålesund meteorological station, which are strongly correlated with data from the Kaffiøyra region. Seasonal statistics presented for temperature and precipitation based on these two sets of data reveal only slight changes. Summer temperatures in the Kaffiøyra region in the studied period (1975-2014) showed statistically significant strong upward trends, while precipitation totals revealed a downward trend, but not statistically significant. In the studied area, based on 40-years of data, it was demonstrated that the near-surface lapse rates of summer air temperature are slightly lower in glaciated $\left(0.58^{\circ} \mathrm{C} / 100 \mathrm{~m}\right)$ than in non-glaciated areas $\left(0.67^{\circ} \mathrm{C} / 100 \mathrm{~m}\right)$. Anticyclonic/cyclonic circulation types significantly increase/decrease air temperature on the Waldemar Glacier, while their impact on precipitation is markedly smaller. In summer, close correlations were observed between air temperature and such glacier characteristics as the mass balance and the location of the equilibrium line, while precipitation does not have a great influence on them.
\end{abstract}

Key words: Arctic, Svalbard, Kaffiøyra, Waldemar Glacier, air temperature, precipitation.

\section{Introduction}

Long-term information about atmosphere characteristics such as air temperature and precipitation in the Arctic, including Spitsbergen, is very important to study changes in other components of the Arctic Climate System (ACS), in particular in the biosphere and the cryosphere (Przybylak 2016). An important obstacle in the improvement of our knowledge about the relationships existing between the mentioned ACS components is a lack of a long series of meteorological observations from glaciated areas. At present, all the regular meteorological 
stations working in Spitsbergen are still located on its western coast, mainly on the tundra area (see Steffensen 1982; Hanssen-Bauer et al. 1990; Nordli 2010; Nordli et al. 2014). However, recent decades have seen a great increase of meteorological observations on glaciated areas (see e.g. Kosiba 1960; Markin 1975; Baranowski 1977; Pereyma 1983; Brázdil et al. 1988; Førland et al. 1997; Wójcik et al. 1997; Migała et al. 2008; Araźny et al. 2010; Bednorz and Kolendowicz 2010; Przybylak et al. 2012a), although at the beginning limited mainly to the summer season and generally to short periods. For some glaciated areas, meteorological series are long enough to check, at least, if climate tendencies observed in tundra areas in the past 3-4 decades are also present in the glaciated areas. Such series of 40 years of data (1975-2014) are available for summer (defined in our case as the period from 21 July-31 August) for the Kaffiøyra region (NW Spitsbergen). Data for this area are available for two diametrically opposed natural environments: the non-glaciated coastal part of the Kaffiøyra Plain and the glaciated part, represented by the Waldemar Glacier. Until now, climate changes in this area have been analysed only for the Kaffiøyra Plain (Przybylak et al. 2011; Araźny et al. 2016). Recently, however, it was assumed that there is enough data to make a reliable reconstruction of the gaps in two series of data available for the Waldemar Glacier.

The main aim of the present paper is to investigate air temperature and precipitation tendencies in recent decades in glaciated areas as opposed to coastal areas. It is commonly known that atmospheric circulation is one of the main factors impacting the climate in Svalbard. Its influence on air temperature and precipitation in coastal, tundra, areas is very well-known (see e.g. Przybylak 1992; Przybylak and Marciniak 1992; Wójcik et al. 1992; Førland et al. 1997; Łupikasza 2010, 2013; Przybylak et al. 2012b; Niedźwiedź 2013). On the other hand, limited knowledge is available for glaciated areas. Therefore, one of the aims of the present paper was also to investigate this issue for the Waldemar Glacier. Measurements of mass balance of the Spitsbergen glaciers began in Finsterwalderbreen in 1950 and were carried out every second year until 1968 (Hagen and Liestøl 1990). Systematic investigations of the mass balance by the Norwegian Polar Institute began in 1966 (Austre Brøggerbreen), in 1967 (Midtre Lovenbreen) and in 1987 (Kongsvegen) (Hagen and Liestøl 1990; Bruland and Hagen 2002). Very early on (in 1965), investigations of glacial mass balance were also initiated by Soviet scientists for Venstre Grønfjordbreen (see Zinger et al. 1966). More systematic investigations of mass balance conducted by Soviet researchers have been carried out on different glaciers mainly in central Spitsbergen during the period from 1973-1986 (Hagen and Liestøl 1990). Later on, Polish scientists also began to measure the mass balance of glaciers in a systematic way: Hans Glacier (S. Spitsbergen) - since 1989 (Migała et al. 2006), Waldemar Glacier (NW Spitsbergen) - since 1996 (Sobota 2013). Based on quite a long series' of such observations, it is possible to improve our knowl- 
edge on the role of the atmosphere in this process. Thanks to the availability of long-term series of summer air temperature and precipitation, their relationships with the summer mass balance and altitude of equilibrium line (ELA) for the Waldemar Glacier were investigated.

\section{Area, data and methods}

Three sets of daily meteorological data were used, taken from a site located near the Nicolaus Copernicus University Base Station (KH), and from two sites located on the Waldemar Glacier - in its firn field (LW2) and immediately at its front (LW1) (Figs 1-2). The KH site lies $200 \mathrm{~m}$ from coast of the Greenland Sea at an altitude of $11 \mathrm{~m}$ a.s.l. Glacier sites (LW1 and LW2) are located about 4 and $6 \mathrm{~km}$ from the coast at altitudes of $130 \mathrm{~m}$ a.s.l. and $375 \mathrm{~m}$ a.s.l., respectively. Przybylak et al. (2011) reconstructed gaps in the mean summer air temperature and precipitation totals for the $\mathrm{KH}$ site based on data from $\mathrm{Ny}$ Ålesund located about $28 \mathrm{~km}$ to the north of our station. For the Waldemar Glacier, measurements of air temperature and precipitation are available for 19 and 15 summer seasons, respectively. For the present paper, both air temperature and precipitation data for the missing summers were reconstructed using high correlations occurring between summer mean/totals of air temperature/ precipitation in $\mathrm{KH}$ from one side and LW1 and LW2 values from the other side. Correlation coefficients exceed the value of 0.9 for both the air temperature and the precipitation (see Figs 3-4).

A catalogue of daily circulation types developed by Niedźwiedź (2015) was used in order to study the influence of the atmospheric circulation on the air temperature and precipitation. Summer mass balance values for the Waldemar Glacier were taken from Sobota (2013), while ELA values from WGMS (2012, 2013).

\section{Results and discussion}

Air temperature. - Air temperature usually decreases with altitude and where non-glaciated areas are overtaken by glaciated surfaces. The highest 40 -year mean summer air temperature in the Kaffiøyra region was recorded at the $\mathrm{KH}$ station $\left(4.9^{\circ} \mathrm{C}\right)$, located near the coast of the Greenland Sea (Table 1, Figs 5 and 6). On the Waldemar Glacier, the mean air temperature was $4.1^{\circ} \mathrm{C}$ in its marginal zone (LW1), which was higher than in the firn field (LW2) by $1.4^{\circ} \mathrm{C}$. The warmest summer in the $\mathrm{KH}$ occurred in $1998\left(6.3^{\circ} \mathrm{C}\right)$, and on the glacier in $2009\left(5.8^{\circ} \mathrm{C}\right.$ in $\mathrm{LW} 1$ and $4.2^{\circ} \mathrm{C}$ in LW2). Such disagreement did not occur in the case of the 


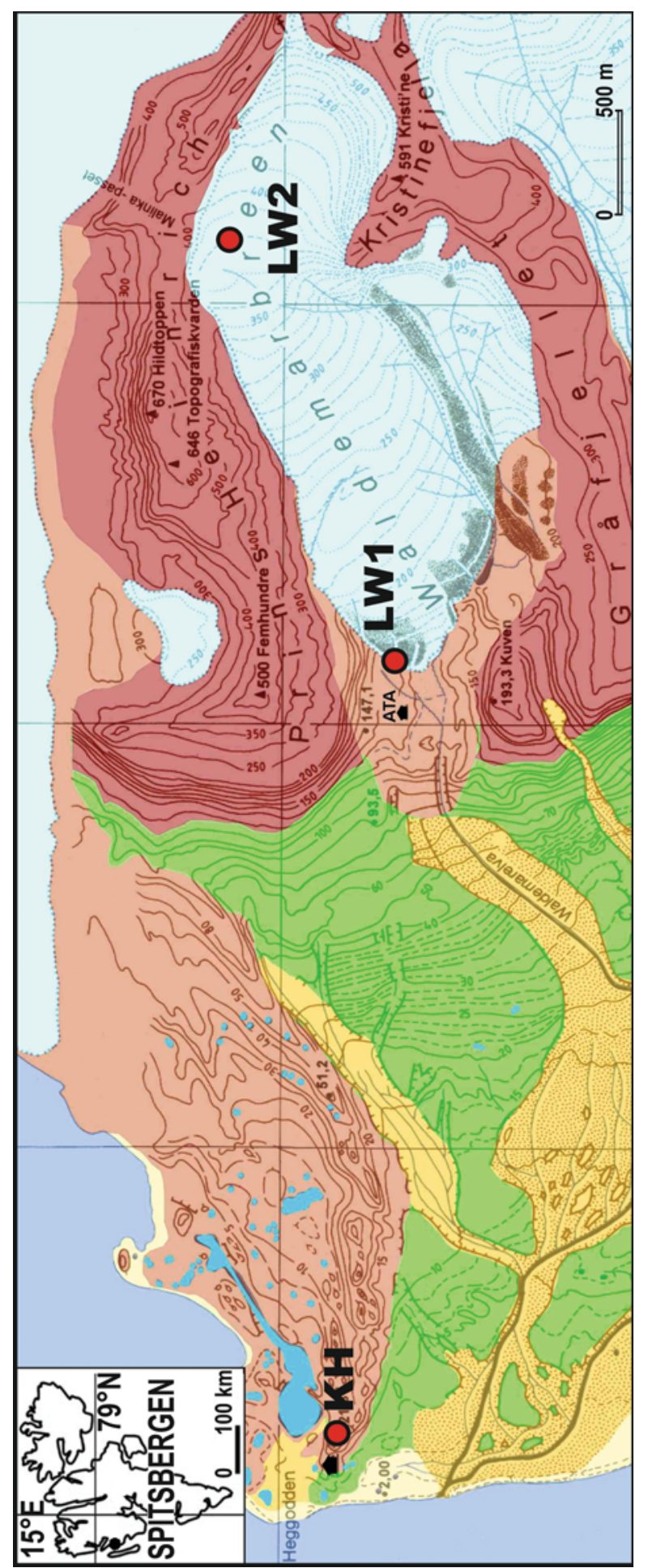

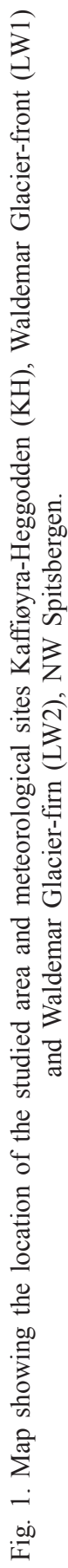




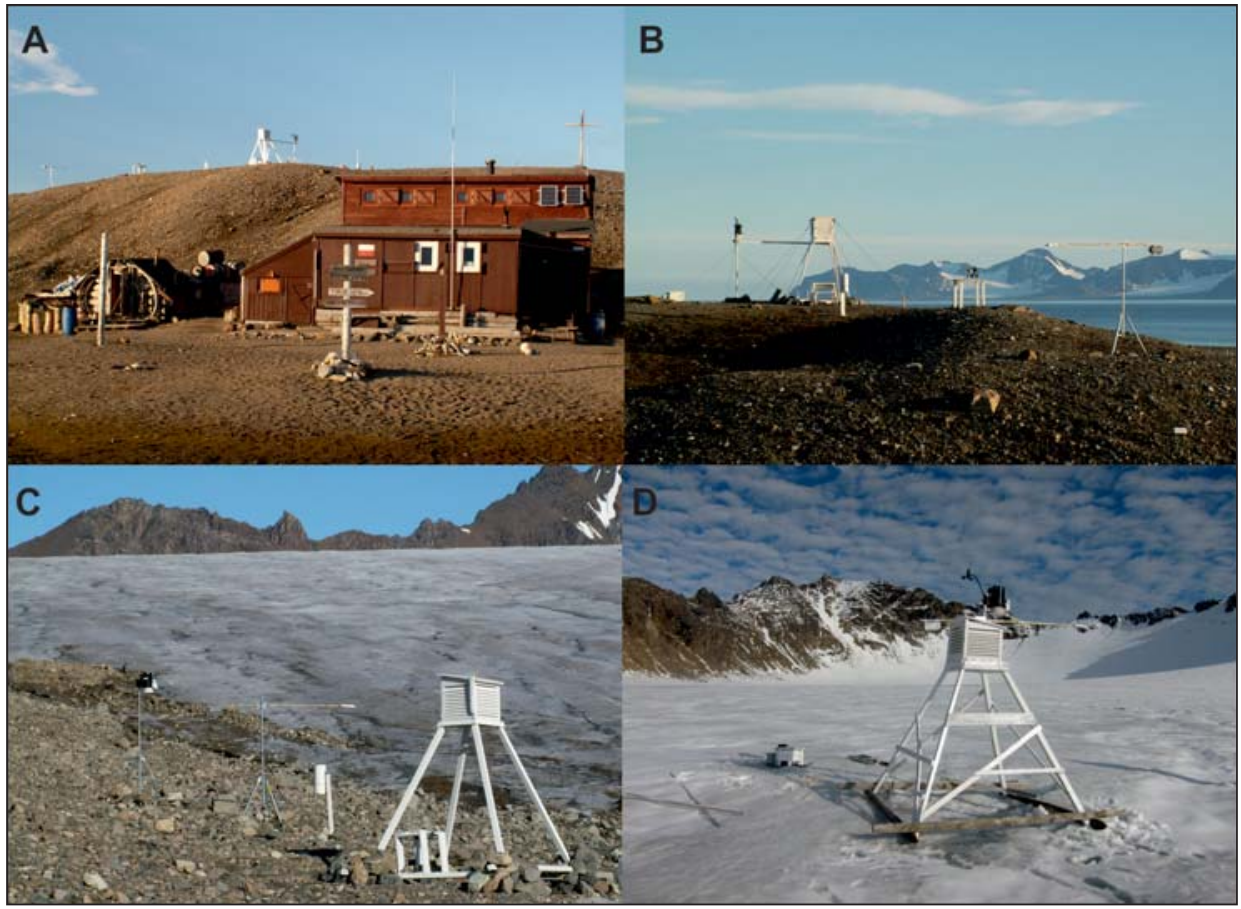

Fig. 2. A - Nicolaus Copernicus University Polar Station, Kaffiøyra, Spitsbergen, B - Meteorological site Kaffiøyra-Heggodden (KH), C - Meteorological site Waldemar Glacier-front (LW1) and D - Meteorological site Waldemar Glacier-firn (LW2).

coldest summer. The coldest temperatures were noted in 1982 at all sites, which was probably related to the El Chichón eruption. In comparison to the air temperature from the summer of 1981, the drop in air temperature exceeded more than $1.5^{\circ} \mathrm{C}$ (see Table 1 and Fig. 5). The effect of Mt. Pinatubo's eruption was also seen in Spitsbergen during the summer of 1992, when the air temperature at all the sites was lower by about $1{ }^{\circ} \mathrm{C}$ in comparison to the air temperature from the neighbouring years. The cold effect of Mt. Pinatubo's eruption was, however, significantly smaller than that of El Chichón.

Statistically significant increases of air temperature at all sites were observed during $1975-2014$, to a range from $0.24^{\circ} \mathrm{C} / 10$ years in $\mathrm{LW} 2$ to $0.3^{\circ} \mathrm{C} / 10$ years in LW1 (Fig. 5). Trends were insignificant until 2000 and then large positive anomalies dominated in almost all the years, except 2008 and 2010 (Fig. 6). Similar results can also generally be observed in summer (defined as JJA) at Svalbard Airport (see Figure 5 in Nordli et al. 2014), although here, the rise of air temperature during 1976-2000 is higher, although still not statistically significant (see Table 9.3 in Przybylak 2002). This behaviour of the air temperature is also in good agreement with the mean summer (JJA) Atlantic Arctic 

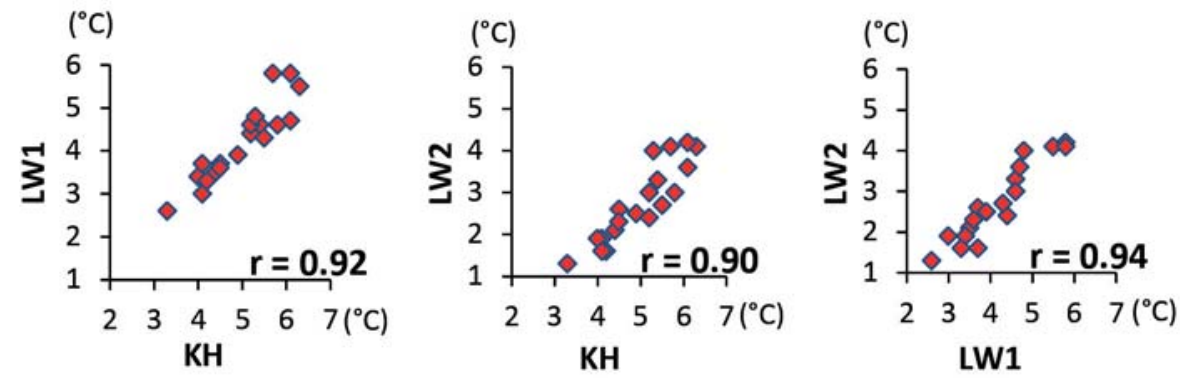

Fig. 3. Relationship between mean summer (21 July-31 August) air temperatures measured at KH, LW1 and LW2 sites.
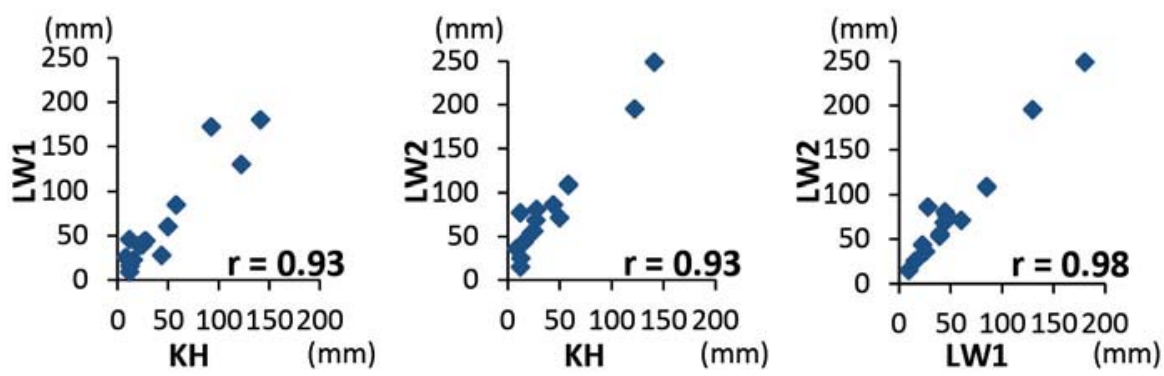

Fig. 4. Relationship between summer (21 July-31 August) precipitation totals measured at KH, LW1 and LW2 sites.

air temperature, where small changes $\left(0.09^{\circ} \mathrm{C} / 10\right.$ years $)$ were observed during 1976-2000 (see Table 9.3 in Przybylak 2002).

Carrying out weather observations on glaciers at the same location, altitude, etc., in particular of the automatic type, involves a number of unfavourable conditions, such as: ablation or accumulation, glacial movement, and termini changes which have shown significant changes in recent decades. Therefore it is very important to reliably estimate the mean rate of the air temperature decrease with the rise of altitude, in particular over glaciated areas. Such knowledge is of a great value for a precise calculation of the mass balance of glaciers and for filling gaps in air temperature series. Migała et al. (2006) showed that the correlation of meteorological variables (air temperature and solar radiation) with the ablation of Hans Glacier was significantly greater when data were taken from glaciers instead of the coastal tundra even if the distance to the glacier is only a few kilometers (see their Table 2).

Research efforts to calculate near-surface lapse rates of air temperature and precipitation in Spitsbergen were undertaken quite early, but were based mainly on relatively sparse measurements (see e.g. Markin 1975; Pereyma 1983; Wójcik 
Table 1

Mean values of summer (21 July-31 August) air temperature (Ti) in the studied area, its near-surface lapse rates (LR) between meteorological sites on Kaffiøyra (KH) and the Waldemar Glacier (LW1 and LW2), 1975-2014.

\begin{tabular}{|c|c|c|c|c|c|c|}
\hline \multirow{2}{*}{ Year } & \multicolumn{3}{|c|}{$\mathrm{Ti}\left({ }^{\circ} \mathrm{C}\right)$} & \multicolumn{3}{|c|}{$\mathrm{LR}\left({ }^{\circ} \mathrm{C} / 100 \mathrm{~m}\right)$} \\
\hline & $\mathrm{KH}$ & LW1 & LW2 & KH-LW2 & KH-LW1 & LW1-LW2 \\
\hline 1975 & 4.9 & 4.1 & 2.7 & 0.61 & 0.68 & 0.57 \\
\hline 1976 & 4.7 & 3.9 & 2.5 & 0.61 & 0.68 & 0.57 \\
\hline 1977 & 5.0 & 4.2 & 2.8 & 0.61 & 0.68 & 0.57 \\
\hline $1978^{\#}$ & 4.4 & 3.5 & 2.1 & 0.63 & 0.76 & 0.57 \\
\hline 1979 & 4.5 & 3.7 & 2.6 & 0.52 & 0.68 & 0.45 \\
\hline 1980 & 4.1 & 3.0 & 1.9 & 0.61 & 0.93 & 0.45 \\
\hline 1981 & 5.2 & 4.4 & 3.0 & 0.61 & 0.68 & 0.57 \\
\hline 1982 & 3.3 & 2.6 & 1.3 & 0.55 & 0.59 & 0.53 \\
\hline 1983 & 4.3 & 3.5 & 2.1 & 0.61 & 0.68 & 0.57 \\
\hline 1984 & 5.2 & 4.4 & 3.0 & 0.61 & 0.68 & 0.57 \\
\hline 1985 & 5.4 & 4.6 & 3.3 & 0.58 & 0.68 & 0.53 \\
\hline 1986 & 4.9 & 4.1 & 2.7 & 0.61 & 0.68 & 0.57 \\
\hline 1987 & 3.8 & 3.0 & 1.6 & 0.61 & 0.68 & 0.57 \\
\hline 1988 & 5.3 & 4.5 & 3.1 & 0.61 & 0.68 & 0.57 \\
\hline 1989 & 4.0 & 3.4 & 1.9 & 0.58 & 0.51 & 0.61 \\
\hline 1990 & 5.0 & 4.2 & 2.8 & 0.61 & 0.68 & 0.57 \\
\hline 1991 & 5.4 & 4.6 & 3.2 & 0.61 & 0.68 & 0.57 \\
\hline 1992 & 4.4 & 3.6 & 2.2 & 0.61 & 0.68 & 0.57 \\
\hline 1993 & 5.3 & 4.5 & 3.1 & 0.61 & 0.68 & 0.57 \\
\hline 1994 & 3.8 & 3.0 & 1.6 & 0.61 & 0.68 & 0.57 \\
\hline 1995 & 5.0 & 4.2 & 2.8 & 0.61 & 0.68 & 0.57 \\
\hline 1996 & 4.2 & 3.4 & 2.0 & 0.61 & 0.68 & 0.57 \\
\hline $1997^{*}$ & 4.2 & 3.3 & 1.6 & 0.72 & 0.76 & 0.69 \\
\hline 1998 & 6.3 & 5.5 & 4.1 & 0.61 & 0.68 & 0.57 \\
\hline 1999 & 4.9 & 3.9 & 2.5 & 0.66 & 0.84 & 0.57 \\
\hline 2000 & 3.9 & 3.1 & 1.7 & 0.61 & 0.68 & 0.57 \\
\hline 2001 & 5.2 & 4.4 & 3.0 & 0.61 & 0.68 & 0.57 \\
\hline 2002 & 5.6 & 4.8 & 3.4 & 0.61 & 0.68 & 0.57 \\
\hline 2003 & 5.6 & 4.8 & 3.4 & 0.61 & 0.68 & 0.57 \\
\hline 2004 & 5.7 & 4.9 & 3.5 & 0.61 & 0.68 & 0.57 \\
\hline 2005 & 5.8 & 4.6 & 3.0 & 0.77 & 1.01 & 0.65 \\
\hline
\end{tabular}


Table 1 - continued

\begin{tabular}{|c|c|c|c|c|c|c|}
\hline \multirow{2}{*}{ Year } & \multicolumn{3}{|c|}{$\mathrm{Ti}\left({ }^{\circ} \mathrm{C}\right)$} & \multicolumn{3}{c|}{ LR $\left({ }^{\circ} \mathrm{C} / 100 \mathrm{~m}\right)$} \\
\cline { 2 - 7 } & $\mathrm{KH}$ & $\mathrm{LW} 1$ & LW2 & KH-LW2 & KH-LW1 & LW1-LW2 \\
\hline 2006 & 5.2 & 4.4 & 2.4 & 0.77 & 0.68 & 0.82 \\
\hline 2007 & 5.5 & 4.3 & 2.7 & 0.77 & 1.01 & 0.65 \\
\hline 2008 & 4.5 & 3.6 & 2.3 & 0.60 & 0.75 & 0.53 \\
\hline 2009 & 6.1 & 5.8 & 4.2 & 0.52 & 0.25 & 0.65 \\
\hline 2010 & 4.1 & 3.7 & 1.6 & 0.69 & 0.34 & 0.86 \\
\hline 2011 & 5.7 & 5.8 & 4.1 & 0.44 & -0.08 & 0.69 \\
\hline 2012 & 5.2 & 4.6 & 3.0 & 0.61 & 0.51 & 0.65 \\
\hline 2013 & 6.1 & 4.7 & 3.6 & 0.69 & 1.18 & 0.45 \\
\hline 2014 & 5.3 & 4.8 & 4.0 & 0.36 & 0.42 & 0.33 \\
\hline $1975-2014$ & 4.9 & 4.1 & 2.7 & 0.61 & 0.67 & 0.58 \\
\hline
\end{tabular}

Explanations: \# $-2-31.08, *-28.07-31.08$, values in italic were reconstructed, see text.

and Przybylak 1985; Brázdil et al. 1988; Wójcik et al. 1998; Migała et al. 2008; Araźny et al. 2010; Bednorz and Kolendowicz 2010; Przybylak et al. 2012a). In the paper, we present the mean values of those lapse rates calculated based on a 40-year period, thus they should be more reliable than those published until now. The mean near-surface lapse rates of air temperature oscillate from $0.61^{\circ} \mathrm{C} / 100 \mathrm{~m}$ to $0.67^{\circ} \mathrm{C} / 100 \mathrm{~m}$ between $\mathrm{KH}$ and $\mathrm{LW} 2$ and $\mathrm{KH}$ and $\mathrm{LW} 1$, respectively (Table 1 ). The mean lapse rate between stations located on the Waldemar Glacier (LW1 and LW2) is $0.58^{\circ} \mathrm{C} / 100 \mathrm{~m}$.

Pereyma (1983) calculated near-surface lapse rates for the area of the Werenskiold Glacier (S. Spitsbergen) for August 1979 (data taken from sites located in the forefront of Werenskiold Glacier and in its firn field), which oscillated around $0.5^{\circ} \mathrm{C} / 100 \mathrm{~m}$. Brázdil et al. (1988) for the summer of 1985 gave a value equal to $1.5^{\circ} \mathrm{C} / 100 \mathrm{~m}$. However, they used air temperature data from the basic meteorological station (Baranowski Station) and from the Werenskiold Glacier's firn field. Such a large value of lapse rate is probably caused by thermal privilege of the first station determined by local conditions. Migała et al. (2008) calculated that the air temperature in Baranowski Station in the summer of 2005 was higher than in the Polish Polar Station in Hornsund ( $c a .12 \mathrm{~km}$ to the south-east) by $0.8^{\circ} \mathrm{C}$. The fact that near-surface lapse rates of the air temperature calculated by Brázdil et al. (1988) for the Bratteggdalen basin (neighbouring area to the Werenskiold Glacier basin) were three times smaller, i.e. they were similar to those obtained by Pereyma (1983), may be also a confirmation of this hypothesis. Migała et al. (2008) calculated mean near-surface air temperature lapse rates at $0.87^{\circ} \mathrm{C} / 100 \mathrm{~m}$ 


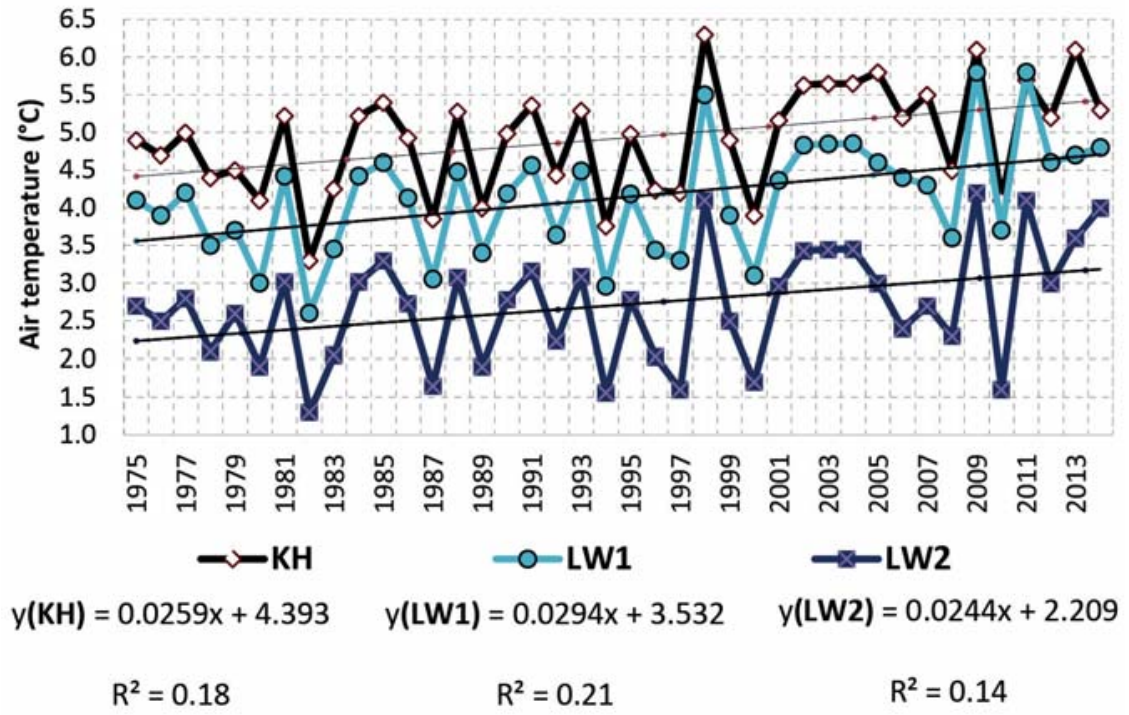

Fig. 5. Reconstructed mean summer (21 July-31 August) air temperature on Kaffiøyra (KH) and the Waldemar Glacier (LW1 and LW2), 1975-2014.

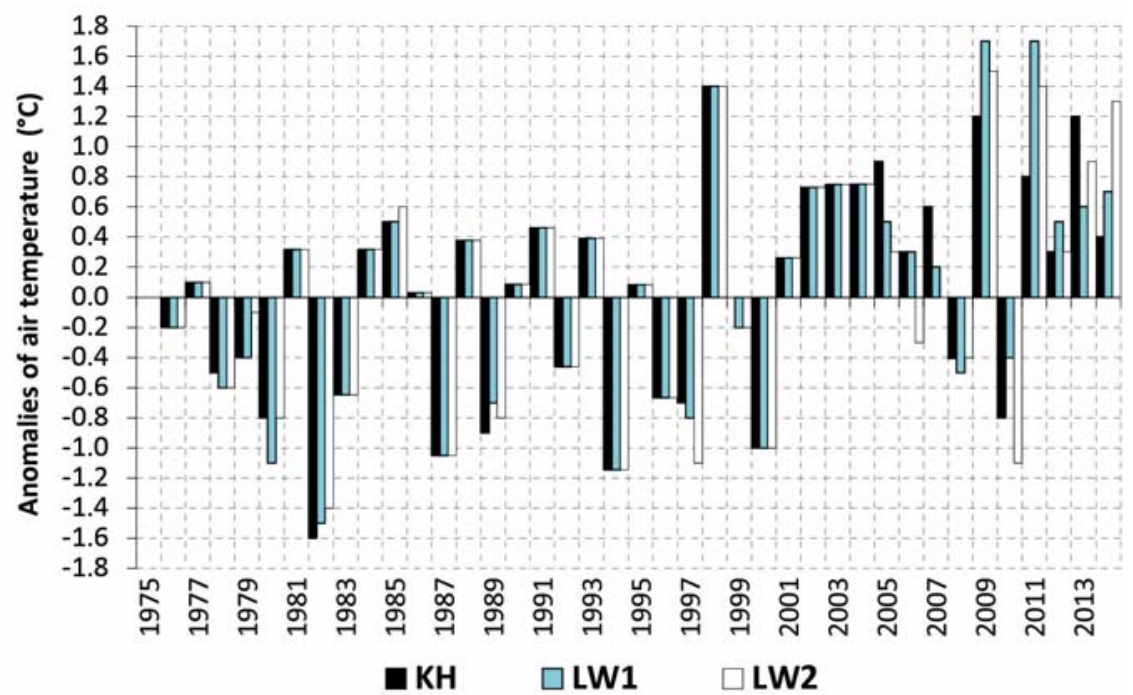

Fig. 6. Anomalies of mean summer (21 July-31 August) air temperature on Kaffiøyra (KH) and the Waldemar Glacier (LW1 and LW2), 1975-2014 (reference period 1975-2014). 
and $0.83^{\circ} \mathrm{C} / 100 \mathrm{~m}$, respectively, for the Werenskiold Glacier basin and the Bratteggdalen basin for the summer (July-September) of 2005. The mean near-surface lapse rates of the air temperature in the Hornsund area reached $0.70^{\circ} \mathrm{C} / 100 \mathrm{~m}$ in the summers of 2007 and 2008 between the site located in the firn field of the Hans Glacier (421 m a.s.l.) and the Hornsund base station (10 m a.s.l.) (Araźny et al. 2010). They noted a lower lapse rate $\left(0.5^{\circ} \mathrm{C} / 100 \mathrm{~m}\right)$ between the Fugleberget summit (568 $\mathrm{m}$ a.s.l.) and Hornsund. A similar value of the near-surface air temperature lapse rate $\left(0.48^{\circ} \mathrm{C} / 100 \mathrm{~m}\right)$ was found by Rodzik and Ryżyk (1987) for the Scott Glacier located in the Bellsund region based on data taken from the snout part (150 $\mathrm{m}$ a.s.l.) and the firn field (480 $\mathrm{m}$ a.s.l.).

Markin (1975) calculated the near-surface value of lapse rate at $0.77^{\circ} \mathrm{C} / 100 \mathrm{~m}$ based on air temperature observations from meteorological stations located in most continental, central, part of Spitsbergen (in Piramiden, $12 \mathrm{~m}$ a.s.l. and Lomonosov Plateau, $1024 \mathrm{~m}$ a.s.l.). A slightly lower lapse rate $\left(0.65^{\circ} \mathrm{C} / 100 \mathrm{~m}\right)$ for this area (Ebba valley) was presented by Bednorz and Kolendowicz (2010). Brázdil and Prošek (1989) calculated the near-surface lapse rate of air temperature $\left(0.7^{\circ} \mathrm{C} / 100 \mathrm{~m}\right)$ for the summer of 1988 for the area of East Grønfjord Glacier located near Barentsburg.

Marshall et al. (2007) estimated the decrease of the summer air temperature in the Prince of Wales Icefield (Ellesmere Island, Canada) at a rate of $0.43^{\circ} \mathrm{C} / 100 \mathrm{~m}$. The values of near-surface air temperature lapse rate calculated for the Langjökull glacier in Iceland (Hodgkins et al. 2013) were higher than in Canada but similar to those found for the southern Spitsbergen.

This review shows that near-surface lapse rates of air temperature calculated based on one or two summer seasons often differ very much from each other and are therefore not a reliable source of information about real topoclimatic differentiation. Long-term data as shown here are necessary. In conclusion, however, one may note that most often near-surface lapse rates of air temperature in Spitsbergen are lower or similar to values of lapse rates occurring in the free atmosphere. In addition, Pereyma (1983) and our investigation results revealed that on glaciers, the near-surface lapse rates are usually lower than in areas covered by the tundra and rocks due to the greater frequency of air temperature inversions over glaciers than over non-glaciated areas (see Wójcik and Przybylak 1985; Wójcik et al. 1998).

Atmospheric precipitation. - For 1975-2014, the average summer precipitation total on the Kaffiøyra Plain, measured using Hellmann's ombrometer was $48.3 \mathrm{~mm}$ (Table 2). The season-to-season variability of summer precipitation totals is very large. For example, at $\mathrm{KH}$, the highest precipitation occurred in $2013(141.4 \mathrm{~mm})$, while the lowest in $2010(8.5 \mathrm{~mm})$. It is well known that precipitation is usually higher in the inner mountain (glaciated) parts of Spitsbergen than in the tundra areas. For example, the mean summer precipitation 
Table 2

Totals of summer (21 July-31 August) atmospheric precipitation (P) in the studied area and its near-surface lapse rates (LR) between meteorological sites on Kaffiøyra (KH) and the Waldemar Glacier (LW1 and LW2), 1975-2014.

\begin{tabular}{|c|c|c|c|c|c|c|}
\hline \multirow{2}{*}{ Year } & \multicolumn{3}{|c|}{$\mathrm{P}(\mathrm{mm})$} & \multicolumn{3}{|c|}{$\mathrm{LR}(\mathrm{mm} / 100 \mathrm{~m})$} \\
\hline & KH & LW1 & LW2 & LW2-KH & LW1-KH & LW2-LW1 \\
\hline 1975 & 66.5 & 89.4 & 170.7 & 28.7 & 19.3 & 33.2 \\
\hline 1976 & 102.2 & 132.8 & 244.5 & 39.1 & 25.8 & 45.6 \\
\hline 1977 & 44.4 & 62.5 & 125.1 & 22.2 & 15.3 & 25.5 \\
\hline 1978 & 44.2 & 62.2 & 124.6 & 22.1 & 15.2 & 25.5 \\
\hline 1979 & 17.7 & 30.0 & 69.9 & 14.4 & 10.4 & 16.3 \\
\hline $1980 *$ & 92.8 & 172.3 & 256.5 & 45.0 & 67.1 & 34.4 \\
\hline 1981 & 63.5 & 85.7 & 164.5 & 27.8 & 18.8 & 32.2 \\
\hline 1982 & 54.5 & 74.8 & 145.9 & 25.2 & 17.1 & 29.0 \\
\hline 1983 & 34.3 & 50.3 & 104.3 & 19.2 & 13.4 & 22.1 \\
\hline 1984 & 34.3 & 50.2 & 104.1 & 19.2 & 13.4 & 22.0 \\
\hline 1985 & 13.9 & 25.4 & 62.0 & 13.2 & 9.7 & 15.0 \\
\hline 1986 & 52.6 & 72.5 & 142.0 & 24.6 & 16.8 & 28.4 \\
\hline 1987 & 47.2 & 65.9 & 130.9 & 23.0 & 15.8 & 26.5 \\
\hline 1988 & 40.8 & 58.1 & 117.6 & 21.1 & 14.6 & 24.3 \\
\hline 1989 & 27.0 & 44.2 & 69.0 & 11.6 & 14.5 & 10.1 \\
\hline 1990 & 36.2 & 52.5 & 108.0 & 19.8 & 13.8 & 22.7 \\
\hline 1991 & 51.0 & 70.5 & 138.7 & 24.1 & 16.5 & 27.8 \\
\hline 1992 & 44.3 & 62.4 & 124.9 & 22.2 & 15.2 & 25.5 \\
\hline 1993 & 64.0 & 86.4 & 165.6 & 27.9 & 18.9 & 32.3 \\
\hline 1994 & 59.0 & 80.3 & 155.2 & 26.5 & 17.9 & 30.6 \\
\hline 1995 & 23.7 & 37.3 & 82.3 & 16.1 & 11.5 & 18.4 \\
\hline 1996 & 61.6 & 83.4 & 160.6 & 27.2 & 18.4 & 31.5 \\
\hline 1997 & 122.5 & 129.8 & 195.5 & 20.1 & 6.2 & 26.8 \\
\hline 1998 & 16.0 & 23.1 & 43.8 & 7.6 & 6.0 & 8.4 \\
\hline 1999 & 58.4 & 85.3 & 108.9 & 13.9 & 22.7 & 9.6 \\
\hline 2000 & 29.1 & 43.9 & 93.4 & 17.7 & 12.5 & 20.2 \\
\hline 2001 & 44.0 & 62.0 & 124.3 & 22.1 & 15.2 & 25.4 \\
\hline 2002 & 124.5 & 160.0 & 290.6 & 45.7 & 29.9 & 53.3 \\
\hline 2003 & 36.2 & 52.6 & 108.2 & 19.8 & 13.8 & 22.7 \\
\hline 2004 & 69.5 & 93.1 & 177.0 & 29.6 & 19.9 & 34.3 \\
\hline
\end{tabular}


Table 2 - continued

\begin{tabular}{|c|c|c|c|c|c|c|}
\hline \multirow{2}{*}{ Year } & \multicolumn{3}{|c|}{ P $(\mathrm{mm})$} & \multicolumn{3}{c|}{ LR (mm/100 m) } \\
\cline { 2 - 7 } & KH & LW1 & LW2 & LW2-KH & LW1-KH & LW2-LW1 \\
\hline 2005 & 49.9 & 60.8 & 71.7 & 6.0 & 9.2 & 4.4 \\
\hline 2006 & 25.0 & 39.8 & 56.2 & 8.6 & 12.5 & 6.7 \\
\hline 2007 & 12.3 & 9.5 & 15.1 & 0.8 & -2.4 & 2.3 \\
\hline 2008 & 22.2 & 39.5 & 53.6 & 8.6 & 14.6 & 5.8 \\
\hline 2009 & 12.5 & 15.9 & 25.4 & 3.5 & 2.9 & 3.9 \\
\hline 2010 & 8.5 & 25.9 & 36.5 & 7.7 & 14.7 & 4.3 \\
\hline 2011 & 28.1 & 44.7 & 81.2 & 14.6 & 14.0 & 14.9 \\
\hline 2012 & 43.9 & 28.2 & 86.6 & 11.7 & -13.2 & 23.8 \\
\hline 2013 & 141.4 & 180.5 & 249.0 & 29.6 & 33.0 & 28.0 \\
\hline 2014 & 12.1 & 45.9 & 77.3 & 17.9 & 28.5 & 12.8 \\
\hline $1975-2014$ & 48.3 & 67.2 & 121.5 & 20.1 & 16.0 & 22.2 \\
\hline
\end{tabular}

Explanations: * 1-31.08; values in italic have been reconstructed, see text.

totals at LW1 and LW2, measured using the same method as in the $\mathrm{KH}$, were greater than at KH by 18.9 and $73.2 \mathrm{~mm}$, respectively. The greatest differences were in 2002, while the lowest in 2007, when even the LW1 precipitation total was lower than at $\mathrm{KH}$. The wettest summer in the tundra areas, glacier lateral moraines and snout of glacier was in $2013(141.4 \mathrm{~mm}$ in $\mathrm{KH}$ and $180.5 \mathrm{~mm}$ in LW1), while the greatest precipitation was observed in $2002(290.6 \mathrm{~mm})$ in the upper part of the glacier (LW2) (Table 2).

A decrease in summer precipitation was observed in the entire studied area, being the greatest $(-0.17 \mathrm{~mm} / 10$ years) at LW2 (Fig. 7). All the trends, however, are not statistically significant. In particular, dry conditions were noted between 2005 and 2012 (Fig. 8). For example, negative precipitation anomalies in LW2, calculated in reference to means from 1975-2014, usually exceeded as much as $40 \mathrm{~mm}$, and in five consecutive years (2006-2010) even more than $60 \mathrm{~mm}$, i.e. precipitation totals during this time were less than $50 \%$ of the long-term average. This can partially be explained by the decrease of frequency of the occurrence of the warm and humid synoptic type Sc+SWc+Wc (Fig. 9). Førland et al. (2011) also showed a summer (JJA) decrease of precipitation in Svalbard, including Ny Ålesund $\sim 30 \mathrm{~km}$ to the north from the studied area, between 1961-1990 and 1981-2010 normal periods. A not statistically significant change (-5.1\%/10 years) in precipitation (see Table 4 in Førland et al. 2011) was noted in Ny Ålesund in the period from 1975-2011.

Summer rain, in particular heavy, occurring on Spitsbergen glaciers, significantly increased the ablation rates (Wójcik et al. 1999; Hock 2005; Migała et al. 2006) and water runoff from glaciers. For this reason, it is essential to know the actual 

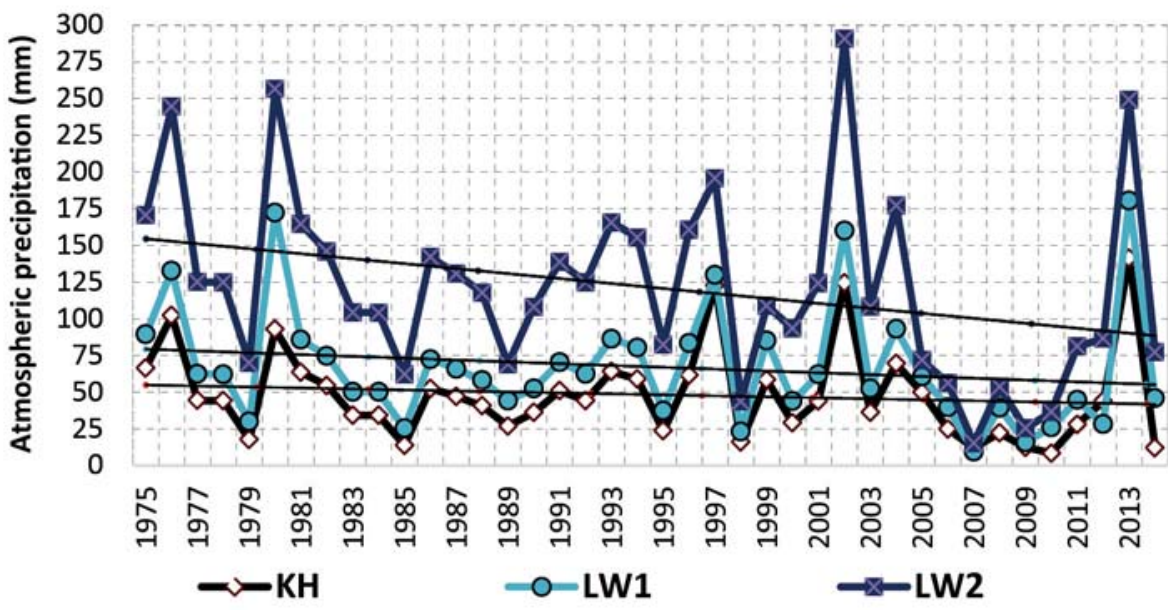

$y($ KH $)=-0.3362 x+55.19 \quad y($ LW1 $)=-0.6207 x+79.96 \quad y($ LW2 $)=-1.6956 x+156.29$

$$
\begin{array}{lll}
\mathrm{R}^{2}=0.02 & \mathrm{R}^{2}=0.03 & \mathrm{R}^{2}=0.10
\end{array}
$$

Fig. 7. Reconstructed summer (21 July-31 August) atmospheric precipitation totals on Kaffiøyra (KH) and the Waldemar Glacier (LW1 and LW2), 1975-2014.

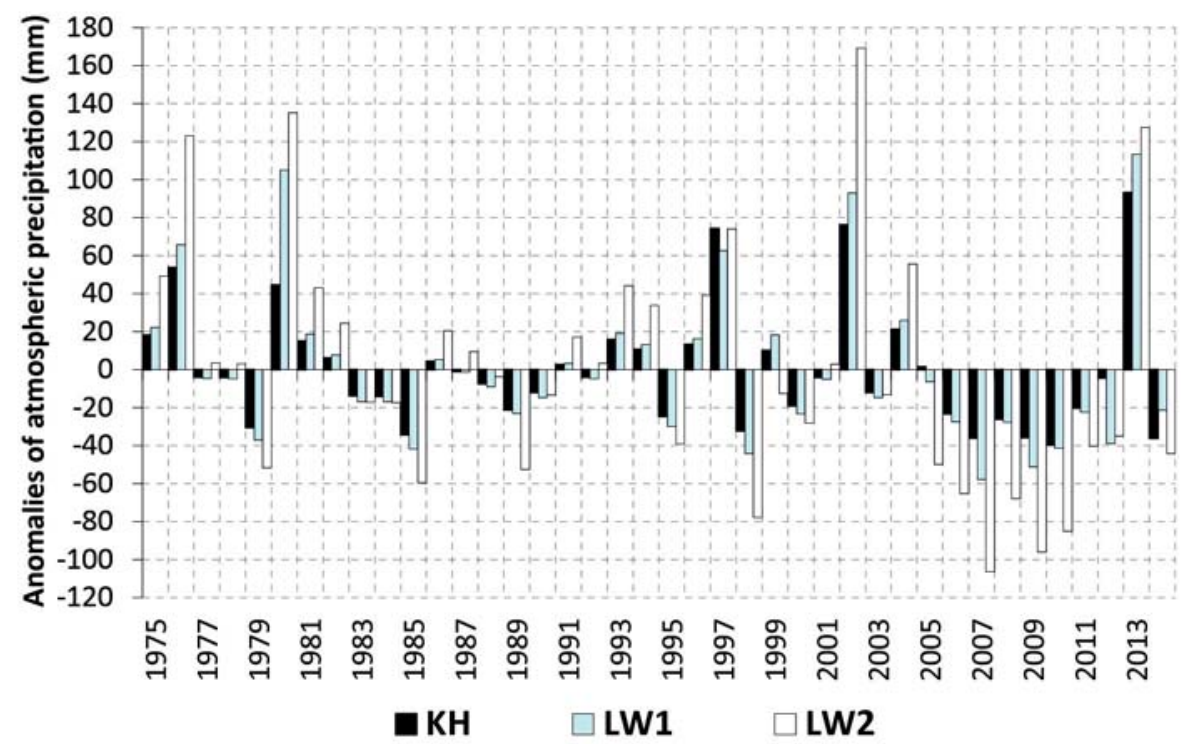

Fig. 8. Anomalies of summer (21 July-31 August) atmospheric precipitation totals on Kaffiøyra (KH) and the Waldemar Glacier (LW1 and LW2), 1975-2014 (reference period 1975-2014). 

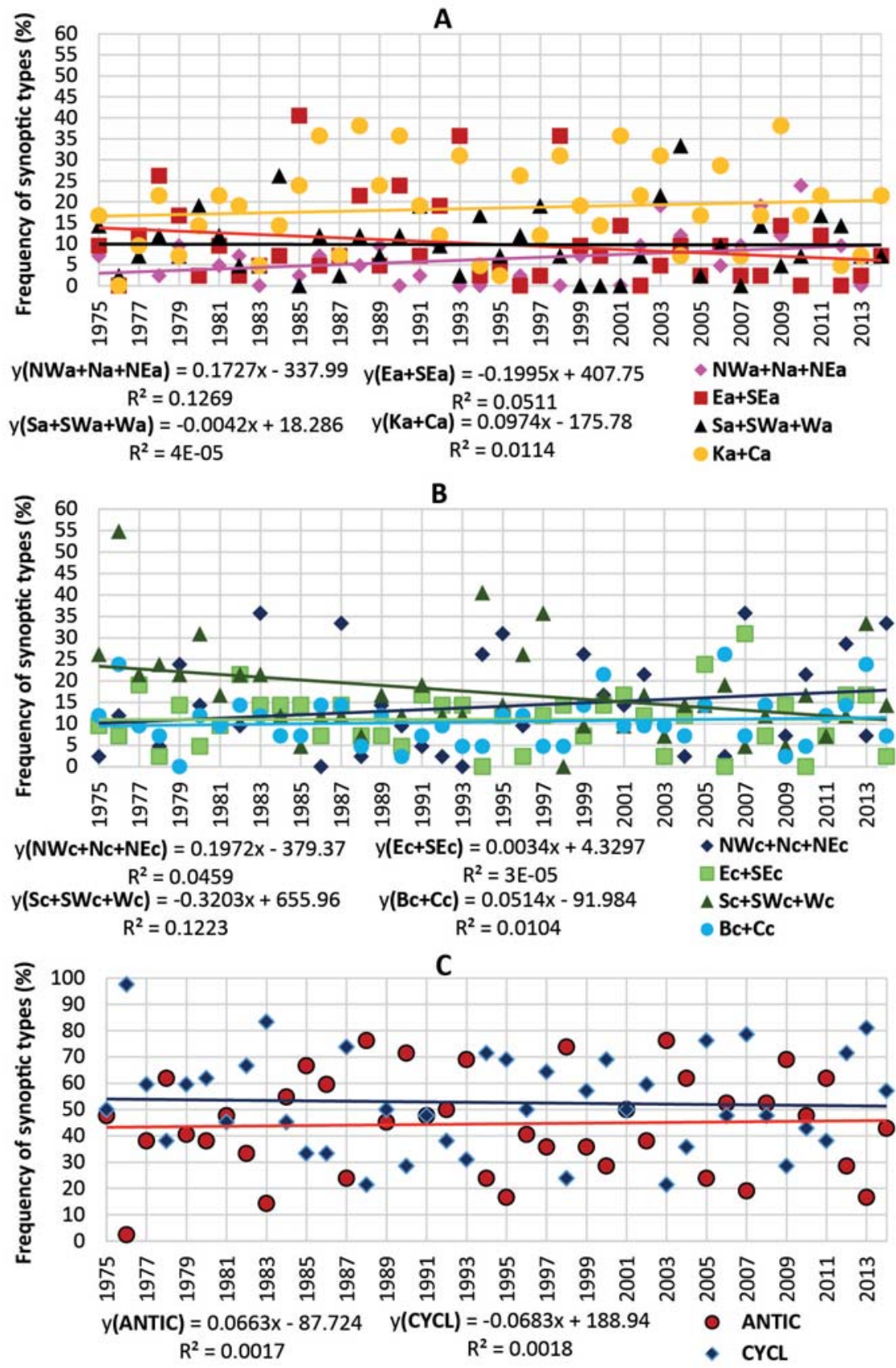

Fig. 9. Frequency of occurrence of combined synoptic types over Spitsbergen in the summer season (21 July-31 August), 1975-2014 and their trends.

Explanations: A) combined anticyclonic types, B) combined cyclonic types, C) all anticyclonic (ANTIC) and cyclonic (CYCL) types. 
amount of this precipitation in glaciated areas. Therefore, measurements of precipitation on glaciers were also initiated quite early, however due to greater difficulty of measurements in comparison to air temperature, significantly less information exists on this phenomenon. Our series is unique for its long time span. The precipitation near-surface lapse rate in the Kaffiøyra region is the highest $(22.2 \mathrm{~mm} / 100 \mathrm{~m})$ between glacier stations (Table 2). Slightly lower values were observed between the tundra and glaciated areas (oscillating from $20.1 \mathrm{~mm} / 100 \mathrm{~m}$ to $16.0 \mathrm{~mm} / 100 \mathrm{~m}$ between KH and LW2 and KH and LW1, respectively). Killingtveit et al. (1994) and Førland et al. (1997) estimated a 5-10\% and 20\% increase of precipitation on Austre Brøggerbreen (located near Ny Ålesund) for every $100 \mathrm{~m}$ increase in altitude, respectively. For central Spitsbergen, Markin (1975) estimated a nearsurface lapse rate of July precipitation for $13 \mathrm{~mm} / 100 \mathrm{~m}$ based on data taken from Piramiden (12 $\mathrm{m}$ a.s.1.) and Lomonosov Plateau (1024 m a.s.l.). In conclusion, one can state that summer precipitation in the firn fields of glaciers located usually about $350-400 \mathrm{~m}$ a.s.l. are about two times greater than in coastal areas where all meteorological stations are located (see also Table 2).

Relationships between weather variables and atmospheric circulation and glacier characteristics. - Atmospheric circulation shows small changes between 1975 and 2014 and - as a result - trends in the occurrence of all the distinguished circulation types are not statistically significant (Fig. 9). However, among the analysed types, the greatest changes were noted in the case of two types: $\mathrm{NWa}+\mathrm{Na}+\mathrm{NEa}$ (frequency increase) and $\mathrm{Sc}+\mathrm{SWc}+\mathrm{Wc}$ (frequency decrease). A statistically significant dependence of air temperature on glaciers from atmospheric circulation was found. Anticyclonic/cyclonic circulation types significantly increase/decrease air temperature on the Waldemar Glacier (Fig. 10). A slightly closer correlation with air temperature revealed anticyclonic weather situations rather than cyclonic ones. However, because the general frequency of both anticyclonic and cyclonic types in summer did not change in the studied period (Fig. 9C), atmospheric circulation was not a reason for the summer air temperature rise in recent decades in Spitsbergen.

Atmospheric precipitation on the Waldemar Glacier in the summer period 1975-2014 revealed significantly lesser relationships with atmospheric circulation than air temperature (Fig. 10). Anticyclonic situations resulted in precipitation decrease, while cyclonic in its increase. A statistically significant correlation of atmospheric circulation with precipitation was found, however, only for LW1 site during cyclonic types $(\mathrm{r}=0.32)$ (Fig. 10).

In summer, close correlations were observed between air temperature, glacier mass balance and equilibrium line altitude, while precipitation did not affect them (Figs 11 and 12). Air temperature significantly reduced the summer mass balance of the Waldemar Glacier, in particular in its lower part. Correlation coefficients between air temperature at LW1 and LW2 from the one side 


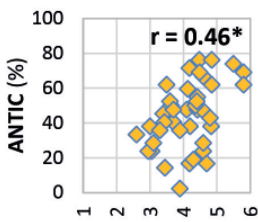

LW1 $\left(\mathrm{Ti},{ }^{\circ} \mathrm{C}\right)$
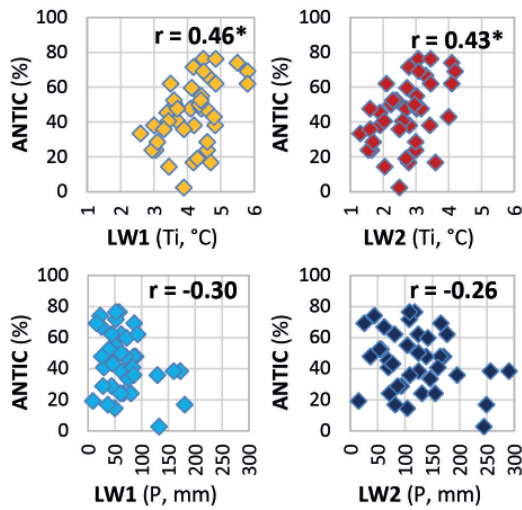

LW2 $\left(\mathrm{Ti},{ }^{\circ} \mathrm{C}\right)$

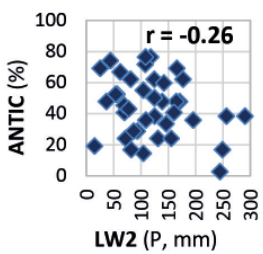

LW2 (P, mm)

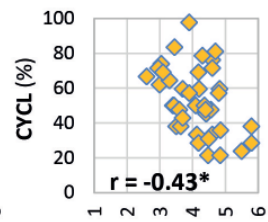

LW1 $\left(\mathrm{Ti},{ }^{\circ} \mathrm{C}\right)$

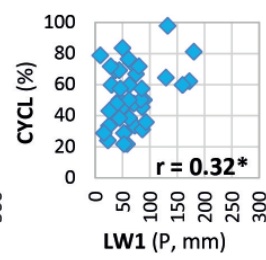

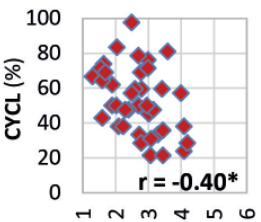

LW2 $\left(\mathrm{Ti},{ }^{\circ} \mathrm{C}\right)$

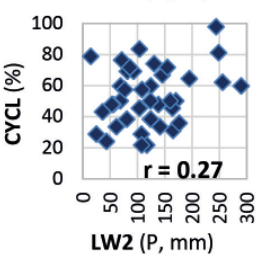

Fig. 10. Correlation between the mean summer air temperature (Ti)/precipitation totals $(\mathrm{P})$ on the Waldemar Glacier (LW1 and LW2) and the frequency of the occurrence of all anticyclonic (ANTIC) and cyclonic (CYCL) types over Spitsbergen, 1975-2014 (upper panel/lower panel, respectively). Explanation: ${ }^{*}$ - correlation coefficients statistically significant at the level of 0.05 .
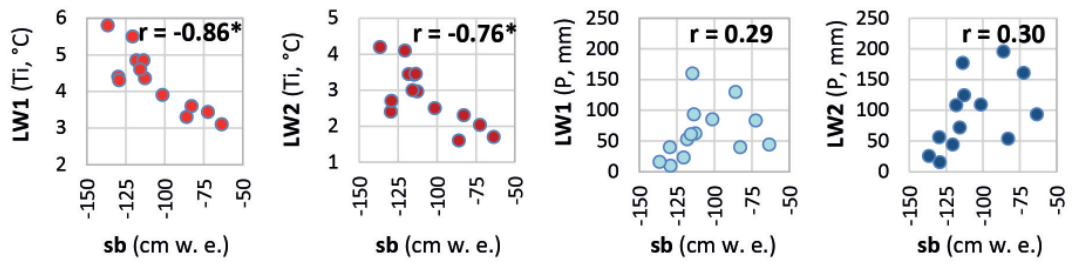

Fig. 11. Correlation between the mean summer air temperature (Ti)/precipitation totals $(\mathrm{P})$ on the Waldemar Glacier (LW1 and LW2) and its summer mass balance (after Sobota 2013), 1996-2009. Explanation: * - correlation coefficients statistically significant at the level of 0.05 .

and summer mass balance from the other side were equal to -0.86 and -0.76 , respectively (Fig. 11). On the other hand, precipitation led to an increase of the summer glacier mass balance, although the relationships were not statistically significant (correlation coefficients oscillate about 0.3). These findings are in good agreement with results presented by Lefauconnier and Hagen (1990), who based on studies of relationships between the annual net balance of Austre Brøggerbreen and climate variables (data from Ny Ålesund) concluded that summer and autumn temperatures, winter precipitation and summer long-wave radiation are the most important factors controlling glacier's behaviour.

As might be expected, the rise of air temperature elevated the equilibrium line altitude (ELA). For the Waldemar Glacier, statistically significant correlations $(r=0.67$ for LW1 and $r=0.65$ for LW2) were found between the ELA and the air temperature above the glacier surface (Fig. 12). In turn, wet summers led to a decrease of the ELA, although relationships were not statistically significant (see Fig. 12). 

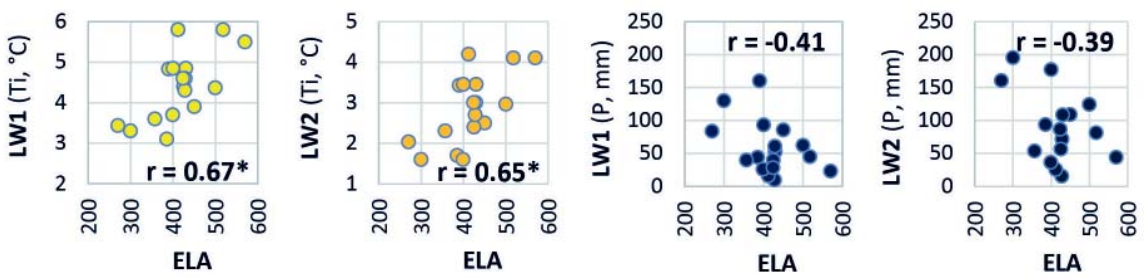

Fig. 12. Correlation between the mean summer air temperature (Ti)/precipitation totals $(\mathrm{P})$ on the Waldemar Glacier (LW1 and LW2) and its equilibrium line (ELA), 1996-2012. Explanations: ELA values after WGMS $(2012,2013)$. Explanation: * - correlation coefficients statistically significant at the level of 0.05 .

\section{Conclusions}

The main results can be summarized as follows.

- Summer air temperature in NW Spitsbergen (including glaciated areas) shows a statistically significant rise in recent decades (1975-2014), in line with other similar works from other parts of Spitsbergen and the Arctic.

- Drying of summer conditions in the studied area is evident, although trends are still not statistically significant. Such behaviour was also noted in other areas located in the western part of Spitsbergen.

- Summer near-surface air temperature lapse rates are variable in Spitsbergen so long-term observations are needed. However, they are usually lower or similar to lapse rates in the free atmosphere. In the studied area, based on 40 -years of observations, it was shown that the near-surface lapse rates of the air temperature are slightly lower in glaciated $\left(0.58^{\circ} \mathrm{C} / 100 \mathrm{~m}\right)$ than in non-glaciated areas $\left(0.67^{\circ} \mathrm{C} / 100 \mathrm{~m}\right)$.

- Precipitation data other than from the regular meteorological stations are very rare in Spitsbergen. In the Kaffiøyra region, the near surface lapse rates of summer precipitation show opposite relationships than those for air temperature. Values of lapse rates are greater on glaciated $(22 \mathrm{~mm} / 100 \mathrm{~m})$ than non-glaciated $(16 \mathrm{~mm} / 100 \mathrm{~m})$ areas.

- Anticyclonic/cyclonic circulation types significantly increase/decrease air temperature on the Waldemar Glacier, however due to their frequency stabilization in period from 1975-2014, atmospheric circulation did not coincided with warming. A significantly weaker influence of atmospheric circulation on precipitation was stated, in comparison to air temperature. A statistically significant rise of precipitation was noted only in the lower part of the Waldemar Glacier during the occurrence of cyclonic circulation $(r=0.32)$.

- In summer, close correlations were observed between air temperature and glacier mass balance and equilibrium line altitude, while the influence of precipitation was negligible. 
Acknowledgements. - The research work was supported by grant entitled 'Contemporary and Historical Changes in the Svalbard Climate and Topoclimates', funded by the National Science Centre with decision No. DEC-2011/03/B/ST10/05007. We also thank Josef Elsner and one anonymous reviewer for helpful comments.

\section{References}

AraźNY A., MigaŁa K., SiKora S. and BudZIK T. 2010. Meteorological and biometeorological conditions in the Hornsund area (Spitsbergen) during the warm season. Polish Polar Research 31(3): 217-238.

ARAŹNY A., PrZYBYlaK R., KeJnA M. 2016. Ground temperature changes on the Kaffiøyra Plain Spitsbergen) in the summer seasons, 1975-2014. Polish Polar Research 37(1): 1-21.

BARANOWSKI S. 1977. The subpolar glaciers of Spitsbergen seen against the climate of this region. Acta Universitatis Wratislaviensis 410: 94 pp.

BEDNORZ E. and KolENDOwiCZ L. 2010. Summer 2009 thermal and bioclimatic conditions in the Ebba Valley region. Polish Polar Research 31(4): 327-348.

BRÁZDIL R. and PROŠEK P. 1989. Climatic conditions of East Grønfjord Glacier. In: A. Olszewski (ed.) Dorobek i perspektywy polskich badań polarnych. XVI Sympozjum Polarne, Toruń, 19-20.09.1989 r., Toruń: 163-165.

BrÁzDIL R., PiASECKi J., ProŠEK P. and SZCZEPANKIEWICZ-SZMYRKA A. 1988. The topoclimatic differentiation of the Werenskiold Glacier and Bratteggdalen regions. In: R. Brázdil, H. Chmal, J. Kida, J. Klementowski, M. Konećný, J. Pereyma, J. Piasecki, P. Prošek, M. Sobik, A. Szczepankiewicz-Szmyrka (eds) Results of investigations of the Geographical Research Expedition Spitsbergen 1985, Univerzita J.E. Purkyné v Brne: 187-210.

BRULAND O. and HAGEN J.O. 2002. Glacial mass balance of Austre Brøggerbreen (Spitsbergen), 1971-1999, modelled with precipitation - run-off model. Polar Research 29(1): 109-121.

FøRLAND E.I., HANSSEN-BAUER I. and NORDLI P.Ø. 1997. Orographic precipitation at the glacier Austre Brøgerbreen. DNMI Rep. 2/97 Klima. Norwegian Meteorological Institute: 45 pp.

Førland E.J., Benestad R., HANSSEN-BAuer I., HAugen J.E. and SKAUgen T.E. 2011. Temperature and precipitation development at Svalbard 1900-2100. Advances in Meteorology. Article ID 893790, 14 pages: DOI:10.1155/2011/893790.

HAGEN J.O. and LIESTøL O. 1990. Long-term glacier mass-balance investigations in Svalbard 1950-88. Annals of Glaciology 14: 102-106.

HANSSEN-BAUER I., SOlas M.K. and STEFFENSEN E.L. 1990. The climate of Spitsbergen. DNMI Rapport 39/90. Klima: 40 pp.

Hock R. 2005. Glacier melt: a review of processes and their modelling. Progress in Physical Geography 29 (3): 362-391.

Hodgkins R., CARR S., PÁLSSON F., GUĐMUNDSSON S. and BJÖRnSSON H. 2013. Modelling variable glacier lapse rates using ERA-Interim reanalysis climatology: an evaluation at VestariHagafellsjökull, Langjökull, Iceland. International Journal of Climatology 33: 410-421.

KillingtVEIT Å., PETTERSON L.A. and SAND K. 1994. Water balance studies at Spitsbergen, Svalbard. Proceedings, Tenth International Northern Research Basin Symposium and Workshop, Spitsbergen, Norway. Foundation for Scientific and Industrial Research, Norwegian Institute of Technology. SINTEF Rep. STF 22A96415: 77-94.

KosIBA A. 1960. Some of results of glaciological investigations in SW-Spitsbergen carried out during the Polish I.G.Y Spitsbergen Expeditions in 1957, 1958 and 1959. Zeszyty Naukowe Uniwersytetu Wrocławskiego, Seria B, Nauki Przyrodnicze 4: 30 pp. 
LEFAUCONNIER B. and Hagen J.O. 1990. Glaciers and climate in Svalbard: statistical analysis and reconstruction of the Brøggerbreen mass balance for the last 77 years. Annals of Glaciology 14: $148-152$.

ŁUPIKASZA E. 2010. Long-term variability of precipitation form in Hornsund (Spitsbergen) in relation to atmospheric circulation (1979-2009). Bulletin of Geography. Physical Geography Series 3: 65-86.

ŁUPIKASZA E. 2013. Associations of precipitation with atmospheric circulation. In: A.A. Marsz and A. Styszyńska (eds) Climate and Climate Change at Hornsund, Svalbard. Gdynia Maritime University, Gdynia: 209-211.

MARKIN V.A. 1975. Climate of area of contemporary glaciation. In: L.S. Troitsky, E.M. Singer, V.S. Koryakin, V.A. Markin and V.I. Mikhalev (eds) Oledeneniye Spitsbergena (Svalbarda). Izdatielstwo Nauka, Moskva: 42-105 (in Russian).

MARShall S.J., SharP M.J., BuRgeSS D.O. and ANSLOW F.S. 2007. Near-surface-temperature lapse rates on the Prince of Wales Icefield, Ellesmere Island, Canada: implications for regional downscaling of temperature. International Journal of Climatology 27: 385-398.

MigAŁA K., PIWOWAR B.A. and PUCZKO D. 2006. A meteorological study of the ablation process on Hans Glacier, SW Spitsbergen. Polish Polar Research 27: 243-258.

MigaŁa K., NasióŁKOWski T. and Pereyma J. 2008. Topoclimatic conditions in the Hornsund area (SW Spitsbergen) during the ablation season 2005. Polish Polar Research 29 (1): 73-91.

NIEDŹWIEDŹ T. 2013. Influence of atmospheric circulation on the air temperature at Hornsund. In: A.A. Marsz and A. Styszyńska (eds) Climate and Climate Change at Hornsund, Svalbard. Gdynia Maritime University, Gdynia: 165-172.

NIEDŹWIEDŹ T. 2015. Catalogue of atmospheric circulation types for Spitsbergen (1951-2014). Katedra Klimatologii Uniwersytetu Śląskiego, Sosnowiec: computer set.

NordLI Ø. 2010. The Svalbard airport temperature series. Bulletin of Geography. Physical Geography Series 3: 5-26.

Nordli Ø., PrZYbylaK R., OGILVIE A.E.J. and ISAKSEN K. 2014. Long-term temperature trends and variability on Spitsbergen: the extended Svalbard Airport temperature series, 1898-2012. Polar Research 33: 21349.

Pereyma J. 1983. Climatological problems of the Hornsund area, Spitsbergen. Acta Universitatis Wratislaviensis 714, Wrocław: 143 pp.

PRZYBYLAK R. 1992. Air temperature and humidity relations at Hornsund (Spitsbergen) in the period 1978-1983 on the background of atmospheric circulation. Dokumentacja Geograficzna 2: 105 pp (in Polish).

PRZYBYLAK R. 2002. Variability of air temperature and atmospheric precipitation in the Arctic. Atmospheric and Oceanographic Sciences Library 25. Kluwer Academic Publishers, Dordrecht/ Boston/London: $330 \mathrm{pp}$.

PRZYBYLAK R. 2016. The Climate of the Arctic. Second edition, Atmospheric and Oceanographic Sciences Library 52, Springer, Heidelberg/New York/Dordrecht/London: 287 pp.

PRZYBYLAK R. and MARCINIAK K. 1992. Atmospheric precipitation and circulation on the western coast of Spitsbergen in the period 1979-1985. Problemy Klimatologii Polarnej 2: 85-95 (in Polish).

PRZYBYLAK R., KEJNA M. and ARAŹNY A. 2011. Air temperature and precipitation changes in the Kaffiøyra Region (NW Spitsbergen) from 1975 to 2010. Papers on Global Changes IGBP 18: $7-21$.

PrZYBylaK R., ARAŹNy A. and KeJNA M. (eds). 2012a. Topoclimatic Diversity in Forlandsundet Region (NW Spitsbergen) in Global Warming Conditions. Oficyna Wydawnicza "Turpress", Toruń: 174 pp. 
PRZYBYLAK R., ARAŹNY A. and KeJNA M. 2012b. Influence of atmospheric circulation on air temperature in the Kaffiøyra region (NW Spitsbergen) in the period July 2005-August 2010. In: Z. Bielec-Bąkowska, E. Łupikasza, A. Widawski (eds) Rola cyrkulacji atmosfery w kształtowaniu klimatu. Prace Wydziału Nauk o Ziemi Uniwersytetu Ślaskiego 74: 181-194 (in Polish).

RODZIK J. and RYŻYK E. 1987. Spatial differentiation of the thermic-humidity conditions of the Bellsund south margin in August 1986. In: J. Repelewska-Pękala, M. Harasimiuk and K. Pękala (eds) XIV Sympozjum Polarne, Lublin, 7-8 maja 1987: 195-199 (in Polish).

SовотA I. 2013. Recent changes of cryosphere of north-western Spitsbergen based on Kaffiøyra region. Wydawnictwo Naukowe UMK, Torun (in Polish): 449 pp.

STEFFENSEN E. 1982. The climate at Norwegian Arctic stations. DNMI Report 5, Klima, Oslo: 44 pp. WGMS. 2012. Fluctuations of Glaciers 2005-2010 (No. X). In: M. Zemp, H. Frey, I. Gärtner-Roer, S.U. Nussbaumer, M. Hoelzle, F. Paul and W. Haeberli (eds) ICSU(WDS)/IUGG(IACS)/UNEP/ UNESCO/WMO. World Glacier Monitoring Service. Zurich, Switzerland. Data based on database version. DOI: 10.5904/wgms-fog-2014-09.

WGMS. 2013. Glacier Mass Balance Bulletin No. 12 (2010-2011). In: M. Zemp, S.U. Nussbaumer, K. Naegeli, I. Gärtner-Roer, F. Paul, M. Hoelzle, and W. Haeberli (eds) ICSU(WDS)/ IUGG(IACS)/UNEP/UNESCO/WMO. World Glacier Monitoring Service. Zurich, Switzerland: 106 pp. Data based on database version. DOI: 10.5904/wgms-fog-2014-09.

WÓJCIK G. and PRZYBYLAK R. 1985. Vertical air temperature gradients on Waldemar Glacier (Oscar II Land, Spitsbergen). XII Sympozjum Polarne, Szczecin: 67-74 (in Polish).

WóJCiK G., MarciniaK K., PrZybylaK R. and KeJnA M. 1992. Air temperature and precipitation on the background of atmospheric circulation in the Kaffiöyra region (NW Spitsbergen) in the summer season in the period 1975-1989. Problemy Klimatologii Polarnej 2: 96-102 (in Polish).

Wójcik G., Kejna M., MarciniaK K., Przybylak R. and Vizi Z. 1997. Meteorological observations on the Oscar II Land (Spitsbergen) and the Bunger Oasis (Antarctica). Oficyna Wydawnicza „Turpress”, Toruń: 412 pp.

WÓJCIK G., MARCINIAK K. and PRZYBYLAK R. 1998. Frequency and intensity of air temperature inversions in summer season in Kaffiöyra region (NW Spitsbergen). Problemy Klimatologii Polarnej 3: 45-68 (in Polish).

WÓJCIK G., MARCINIAK K. and PRZYBYLAK R. 1999. Ablation of Waldemar Glacier (Oscar II Land, NW Spitsbergen) in summer seasons of 1977, 1978 and 1980. Problemy Klimatologii Polarnej 9: 81-102 (in Polish).

Zinger E.M., Koryakin V.S., Lavrushin YU.A., Markin V.A., Mikhalev V.I. and TroitsKIY L.S. 1966. Investigation of Spitsbergen glaciers by Soviet expedition in summer 1965. Materialy Glyatsiologicheskikh Issledovaniy. Khronika, Obsuzhdeniya 12, Moskva: 59-72 (in Russian). 